\title{
Islamic Garden Concept in Response to Landscape Design
}

\author{
Haza Hanurhaza Md Jani¹, Nor Zalina Harun², \\ Mazlina Mansor², Ismawi Zen ${ }^{3}$
}

\author{
${ }_{1}^{1}$ Postgraduate Student, \\ ${ }^{2}$ Senior Lecturer, Department of Landscape Architecture, \\ ${ }^{3}$ Professor of Landscape Architecture, \\ Kulliyah of Architecture and Environmental Design,
} International Islamic University Malaysia, Jalan Gombak, Kuala Lumpur, 53100, Malaysia hanurhaza@gmail.com,nzalina76@gmail.com, mazlina.mansor@gmail.com

\begin{abstract}
This paper discusses on the Islamic garden concept in response to the heterogeneous society in Malaysia. The aim of this paper is to develop an understanding regarding the Islamic garden concept in the context of a heterogeneous society. The findings of the paper will assist in strengthening the understanding and appreciation towards the Islamic garden concept, as well as the implementation of the concept in the landscape design. The paper will relate the idea of Islamic garden concept to the landscape design towards creating an environmental setting in the era of urban regeneration.

Keywords: Islamic garden, Heterogeneous society, Landscape design; Malaysia.

eISSN 2514-751X C 2018. The Authors. Published for AMER ABRA cE-Bs by e-International Publishing House, Ltd., UK. This is an open-access article under the CC BY-NC-ND license (http://creativecommons.org/licenses/bync-nd/4.0/). Peer-review under responsibility of AMER (Association of Malaysian Environment-Behaviour Researchers), ABRA (Association of Behavioural Researchers on Asians) and cE-Bs (Centre for EnvironmentBehaviour Studies), Faculty of Architecture, Planning \& Surveying, Universiti Teknologi MARA, Malaysia.

https://doi.org/10.21834/aje-bs.v3i11.332
\end{abstract}




\subsection{Introduction}

The Islamic civilization spanned from the seventh to the 16th century (Safei Hamed, n.d.). It starts from the establishment of the first Islamic State in Medina to the peak of the Ottoman Empire. The Islamic civilization managed to dominate an era, encompassed half the world, and shaped the history of the human race (Spahic Omer, 2005). Through the influences of the Islamic rulers, several prominent Islamic gardens were developed, for instance, in Western Asia (Iran, Turkey, and the Arabian Peninsula), Southeastern Asia (India, Pakistan, Kashmir, Uzbekistan, and Afghanistan), The Middle East (Syria, Lebanon, Iraq, Palestine, Egypt, Morocco, and Tunisia) and Europe Spain (Granada, Cordova, Seville and Toledo). The development of the Islamic garden expanded from one region to another, and some of the remaining evidence managed to be preserved. However, the physical evidence may have gradually lessened due to change of ruler and the falls of Islamic governance, especially after the Ottoman Empire.

Nevertheless, the Islamic gardens such as the Generalife Al-Hamra, Spain; Mughal garden and Taj Mahal, India are among the cherished gardens during the Islamic civilization that remain as a legacy of the influential era of Islamic rulers. However, the prominent Islamic gardens focused more towards the Middle East countries, as the area is predominant with Muslim society; therefore, the garden evolved around the city was developed based on the Islamic principles. Nonetheless, this research will shed light on the Asia perspective on the idea of Islamic garden, specifically in Malaysia. For that reason, the aim of this study is to understand the Islamic garden concept in response to the heterogeneous society in Malaysia. The study will discover the relevance of the Islamic garden from the local context, Malaysia. In order to reach the aim of the study, the objectives are highlighted as follows: to understand the development of the Islamic garden concept, to explain the relationship between Islamic garden concept and the heterogeneous society and finally, to examine the relevance of the Islamic garden concept in response to the heterogeneous society in Malaysia. A study on the issues of the Islamic garden needs to be undertaken to ascertain that the understanding and appreciation towards Islamic garden are still being practiced. For that reason, this paper is developed in order to maintain and continue the legacy of the Islamic rulers.

\subsection{Literature Review}

In order to define the Islamic garden; it is important to firstly develop the understanding on the Islamic city-state, as the keywords are inter-correlated between one another. The first establishment of the Islamic city-state was the Medina city during the sixth century. It was called as the first Islamic city-state due to the formation of the first Islamic law which is the Medina charter. The purpose of the charter is to encourage peace among the heterogeneous societies, and the establishment of the Medina charter manages to bring the multi-tribes and multi-ethnicity together under the influence of Islamic philosophy and laws. The Medina charter was first established in the $622 \mathrm{AD}$, by the Prophet Muhammad PBUH for the citizen in Medina. The charter is perceived as a tool for conflict resolution, due to the intense fights among the tribes during the time (Nagy, 2002; and Yildirim, 2009). It was the first written 
constitution that took accounts the well-being of Muslim and non-Muslim, and it specifically identified the parties involved in the conflict in Medina. Besides, the charter was explicitly designed to suit the heterogeneous society in which the rights of the citizen are equally highlighted, and they have the same rights to offer their opinion on the governmental matters (Kassim Ahmad, 2007). Therefore, the question of adapting the Islamic garden into the city or garden planning in the heterogeneous society is no longer an uncertain issue, as the success of the Medina charter has proven the relevance of the implementation.

\subsection{Islamic Garden}

Formerly, the Islamic garden was designed as the earthly symbol of paradise. The term Islamic garden was first acknowledged during the establishment of the Persian garden in the seventh century (Haaga, 2005). It is claimed as the basis for the Islamic garden and the inspiration of the Persian garden has been adopted in several other prominent Islamic gardens, for instance, the Moghul gardens in Kashmir, India and the Alhambra and the Generalife, Southern Spain. The influence of the Spain garden has spread throughout the world until the $20^{\text {th }}$ century, and the evidence of the influence can be traced for instance, the revival garden in California and Mexico. The Islamic garden promotes the concept of simplicity, and; therefore, the sense of the Islamic garden are well adapted in the modern world. Petruccioli (1998) states, the inspiration for the Islamic garden, first catch the attention of the European culture during the $17^{\text {th }}$ century. The Islamic garden is perceived as one of the seductive symbols of a new exotic world, describes as a place where the novel taste for space and decoration was freely expressed. The influence of the Islamic garden can be seen through the garden design in Florence and the Royal Pavilion of Brighton, England. In the $19^{\text {th }}$ century, the expansion of the Islamic garden's influence has become a glamorous fashion whereby it was selected as one of the official architectural styles in the World Fairs. The influences of the Islamic garden continue throughout the $19^{\text {th }}$ century until the beginning of the $20^{\text {th }}$ century, before it slowly disappears due to the modern movement.

It is discovered that the establishment of the Islamic garden starts around the seventh century. The earliest design of the Islamic garden emphasized on the concept of privacy in the garden design (Germeraad, 1993). Throughout the century, the implementation of the Islamic garden has slowly been adapted into the garden design. There are several prominent Islamic garden recognized after the establishment of the Persian garden which is the Mughal garden, Kashmir and Al-Andalus, Spain. Nevertheless, what is the term applied to for a garden with the Islamic basis or philosophy before the creation of the Persian garden? Islamic garden or garden in general is part of the open space created for public uses. Before the creation of the Persian garden, the garden is referred to only as part of an open space. After the development of the Islamic city-state, several Muslim rulers start to embed the Islamic concept into the garden design for instance, the fourth Mughal Emperor Jahangir (15691627) who constructed the black pavilion in Kashmir (Sajjad Kausar, 2005).

Seyyed Hossein Nasr et al., (1993) highlighted on the term 'Islamic' by Gulzar Haider. The basis on an Islamic environment or garden is not through the development of patterns or structures. However, the atmosphere that the garden encourages is the key element that 
defines the Islamic garden. It is the environment that stimulates the memory of God and displays the values embedded the concepts of tawhid (ones of god), Khalifah (vicegerent), khilqat (environment), jihad (devotion), adl (fairness), ibadah (worship), ilm (knowledge) and jamal (beauty) highlighted in the al-Quran. Therefore, any garden that supports the similar values is considered Islamic (Gulzar Haider, 1984).

\subsection{Heterogeneous Society}

The heterogeneous society in this study refers to the case study area which is Malaysia. According to Snodgrass (1995), "Malaysia is the veritable model of heterogeneous, multiethnic, or plural society." The statement describes the population of the country that comprises of multiple ethnicities, dominated by the Malays (62 percent) and is recognized as an ethnically heterogeneous country. Ataul Huq Pramanik (2002) supported the statement by addressing Malaysia as one of the successful heterogeneous country under Muslim rulers. He further explains the extent of the Islamic force in the context of a heterogeneous society in Malaysia. Ethnicities comprise of different background; culture and tradition come together under the influence of a Muslim Country are bound by fundamental core values of Malays based on justice (al adlwa al ihsan), tolerance (al-tasamuh) and compassion (al-Rahmah) to achieve a peaceful country (Anwar Ibrahim in Osman Bakar, 1997, pp 11-17). As Mahathir (1999) pointed out, Malaysia is a country dominated by Muslim, who prefers to protect their friends and enemies from humiliation, and this has become the strong bond that holds the heterogeneous society in the country.

Oh John (1967) describes heterogeneous society as a population with diverse ethnic background surrounded with numerous capacities and aspirations. However, due to the different ethnic background, there is a possibility of political instability. It was pointed out that Malaysia is a society of great diversity and contrast in term of geography, economics, culture, religion, community, and language. Hence, the possibility of political instability is still a questioning issue. However, Economic Planning Unit (2004) defines heterogeneous as 'multiracial' consist of several races, namely, the Malays, Chinese, Indian and others races; and Malaysia is the example of the heterogeneous society that can maintain the racial harmony for almost 57 years. Norliza Mohd Isa (2011) emphasizes on the similar perspective on the definition of the heterogeneous society, as a country, with diverse culture that practiced multi-religious. From the local point of view, Malaysia is an excellent example of a heterogeneous society's predominant by the Muslim. Dissimilar situation happened in Pakistan, Muntzra Nazir (2008) expresses on the issue of federalism on governance and political management in the country even after sixty years of freedom. Federalism is the attempt to accommodate the heterogeneous society in the county to accommodate divergent regional, ethnic and linguistic identities. Pakistan is now working hard to resolve their issues in keeping the unity in diversity and to promote harmony.

Based on the discussion, heterogeneous society can be described as a multicultural, multiracial and multi-religious society within a community or country. According to the literature, it can be stated that there are advantages and disadvantages for a country with heterogeneous societies, however, the success and failure is rather subjective. Therefore, in 
general, the term heterogeneous implies the idea of having different elements. Merkel and Weiffen (2012) describes heterogeneous as the socio-cultural complexity and differentiation of social structures in modern societies. Previously, most research indicates the concept of heterogeneous as 'sub-culture division' or 'plural' (Kuper and Smith, 1969; Singh and Rex, 2003; Mohd Anuar Ramli and Mohammad Aizat Jamaludin, 2012; and Merkel and Weiffen, 2012). Nevertheless, the term still revolves around the similar definitions mentioned.

\subsection{Methodology}

This study is based on the qualitative research methodology. In order to have a better understanding of the Islamic garden concept and the heterogeneous society, document analysis is adopted. A document analysis is perceived as part of a qualitative research method in which a document is interpreted based on the assessment issues. According to Mogalakwe (2006), there are two types of document analysis, which are the interpretation of the primary and secondary document. A secondary document is chosen for the purpose of this study. The documents have been categorized into three sections which are the Islamic garden concept, the Islamic city planning and the heterogeneous society (refer to Figure 1).

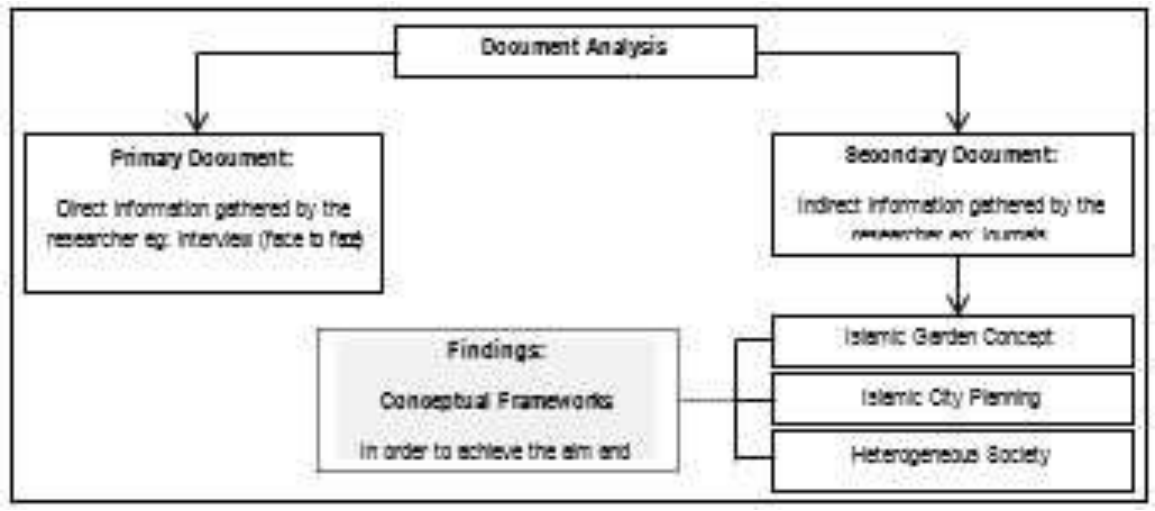

Figure 1: Document analysis

\subsection{Results and Discussions}

The findings are divided into two main sections based on the variables highlighted from the objectives of the study, which are the Islamic garden and the heterogeneous society. It is discovered that the earliest sign of the Islamic garden begins in the seventh century. The Persian garden is most probably the main influence of the Islamic garden concept as it manages to inspire other garden design such as in Mughal garden, Kashmir. Nevertheless, the garden is described as Islamic when the environment encourages remembering God and displaying the Islamic values into the garden design. The Islamic values comprise of eight 
principles which are the ones of God, vicegerent, environment, devotion, fairness, worship, knowledge and beauty. These are among the principles promoted in the Islamic garden design.

Through the literature on the Islamic city-state and Medina charter, it is realized that the heterogeneous society accepts the Islamic law (values and principles) since the $622 \mathrm{AD}$. Hence, the issue of trying to embed the Islamic garden into the garden design of a heterogeneous society is proven relevance. Besides, in the heterogeneous country such as Malaysia, the country is bound by the fundamental core values which are justice, tolerance and compassion. Therefore, these have become the strength of the heterogeneous society in the country. Based on these, the conceptual frameworks on the findings are presented as follows:

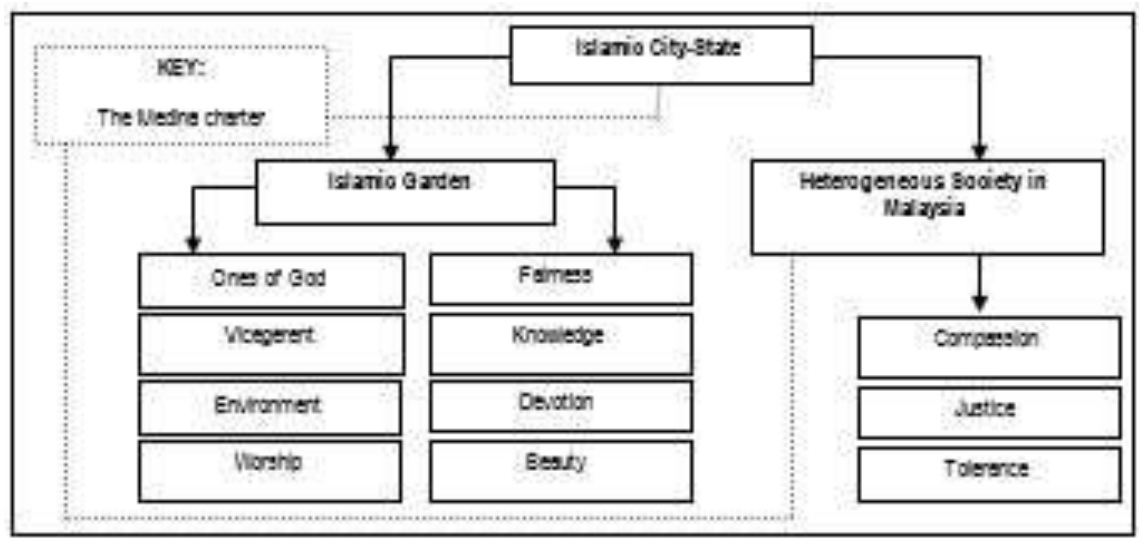

Figure 2: Conceptual frameworks

\subsection{Conclusion}

The idea of Islamic garden arises in the early century, after the establishment of the first Islamic city-state, Medina. Persian garden is the earliest evidence of the Islamic garden which take place in the seventh century. Since then, the idea of Islamic garden has become an inspiration to landscape design. The idea spreads out until the early $20^{\text {th }}$ century where the modernization has slowly interfered with the Islamic garden concept. Due to modernization, the implementation of the Islamic garden has slowly decreased and disappearing. Besides, another contributing factor to the decreasing number of Islamic garden is due to the falls of the Muslim civilization and empire. This has led to the limited access to the physical evidence of the Islamic garden. Hence, the study on the Islamic garden is perceived as an important strategy in order to preserve the legacy of the Muslim empire. Other than that, it is important to highlight that the Islamic garden is not limited to the pattern, form or structure. The Islamic garden promotes the environment that can stimulate the appreciation towards God. The 
statement suggests that any gardens that have the eight principles will be considered as Islamic garden.

\section{References}

Ataul Huq Pramanik. (2002). Islam and development revisited with Evidences from Malaysia. Islamic Economic Studie, 10(1), 39-74

Germeraad, P. W. (1993). Islamic traditions and contemporary open space design in Arab-Muslim settlements in the Middle East. Landscape and Urban Planning, 23(2), 97-106.

Gulzar Haider. (1984). Habitat and values in Islam: A Conceptual Formulation of an Islamic City. In Ziauddin Sadar (Eds.), The Touch of Midas (pp. 170-208). England: Manchester University Press.

Haaga, Elin. (2005). Paradise in the Garden: the influence of the Islamic Garden Today. West Looks East: The Influence of Traditional Arab Design on contemporary Western Designers. Retrieved from http://www.mosaicfound.org/sc/cultural_media/wle_Haaga_bio

Kuper, L., \& Smith, M. G. (Eds.). (1969). Pluralism in Africa. Berkeley: University of California Press.

Kassim Ahmad. (2008). A Short Note on the Medina Charter. Retrieved on 10 May 2014 from http://www.constitution.org/cons/medina/kassim2.htm

Mahathir Mohamad. (1999). The Malay Dilemma. Kuala Lumpur: Times Books International.

Mogalakwe, M. (2006). The use of Document Research Methods in Social Research. African Sociological Review, 10(1), 221-230.

Mohd Anuar Ramli \& Mohammad Aizat Jamaludin. (2012). Interaction of Plural Society in Malaysia: Diatribe or Dialogue. World Journal of Islamic History and Civilization, 2(1), 53-57.

Merkel, W., \& Weiffen, B. (2012). Does Heterogeneity Hinder Democracy?. Comparative Sociology, 11, 387-421

Muntzra Nazir. (2008). The Problems and Issues of Federalism in Pakistan. Journal of Pakistan Vision, 9(1), 109128.

Nagy, N. (2002). Prophet Muhammad (Peace Be Upon Him). Egypt: Bibliotheca Alexandrina

Norliza Mohd Isa. (2011). Cities Design and Planning with People's Perception Consideration A Methodology To Elicit The Perceptions Of Experts On The Meaning Of Islamic Built Environments in Malaysia. In: N-AERUS XII, 2022th October 2011, Madrid.

Oh John, C. H. (1967). The Federation of Malaysia: An Experiment In Nation-Building. American Journal of Economics \& Sociology, 26(4), 425-438.

Osman Bakar. (Eds.). (1997). Islam and Confucianism - A Civilizational Dialogue. Kuala Lumpur: Center for Civilizational Dialogue, University Malaya.

Petruccioli, A. (1998). Rethingking the Islamic Garden. In Transformation of Middle Eastern Natural Environment: Legacies and Lessons, ed. Jane Coppock and Joseph A. Miller. New Haven: Yale University Press, pp. 349-363. 
Md Jani, H.H., et.al., / Asian Journal of Environment-Behaviour Studies (ajE-Bs), 3(11) Nov / Dec 2018 (p.38-45)

Seyyed Hossein Nasr, Zaini Ujang, Ziauddin Sardar. (1993). Islam dan Alam Sekitar (Cet. 1. ed.). Kuala Lumpur: Institut Kajian Dasar.

Spahic Omer. (2005). Issues in the History and Character of the Islamic Built Environment. Kuala Lumpur: International Islamic University Malaysia.

Singh, G., \& Rex, J. (2003). Pluralism and Multiculturalism in Colonial and Post-Colonial Societies. International Journal on Multicultural Societies (IJMS), 5(2), 106-118

Safie Hamed. (n.d.). The Gardens of Islam: Earthly Paradise Revisited. Department of Landscape Architecture. Lecture conducted from Texas Tech University, Texas, United States.

Sajjad Kausar. (2005). Meaning Of Mughal Landscape. In the 10th International Seminar 'Cultural Landscapes in the 21st Century': Newcastle Upon Tyne, 11-15 April.

Snodgrass, D. R. (1995). Successful Economic Development in a Multi-ethnic Society: the Malaysian case. Cambridge: The Harvard Institute for International Development.

Yildirim, Y. (2009). The Medina Charter: A Historical Case of Conflict Resolution. Islam and Christian-Muslim Relations,20(4), 439-450. 